\title{
AN ANALYSIS OF BRAHMACĀRIN ETHICS IN MANAWA DHARMAÇASTRA (HINDU LAW COMPENDIUM)
}

\author{
Puspo Renan Joyo ${ }^{1}$, Ni Kadek Surpi² \\ ${ }^{1}$ Institut Agama Hindu Negeri Tampung Penyang Palangka Raya \\ ${ }^{2}$ Universitas Hindu Negeri I Gusti Bagus Sugriwa Denpasar \\ 1 pusporenanjoyo@iahntp.ac.id, ${ }^{2}$ dosen.surpiaryadharma@gmail.com
}

\begin{abstract}
Abstrak
Penelitian ini bertujuan untuk mengungkap etika brahmacārin di dalam kitab Manawa Dharmaçastra. Penelitian ini merupakan penelitian kepustakaan (library research), dengan jenis penelitian kualitatif. Metode dalam penelitian adalah deskriptif, dengan menggunakan analisis deskriptif interpretatif. Teori yang digunakan adalah teori Hermeneutika Hans-Georg Gadamer. Sumber data primer dalam penelitian ini adalah kitab Manawa Dharmaçastra. Berdasarkan kajian yang telah dilakukan, maka dapat diungkap etika brahmacārin dalam tinjauan kompendium hukum Hindu (kitab Manawa Dharmaçastra) sebagai berikut: kewajiban bhakti kepada tuhan dan ācārya; kewajiban berbusana bersih dan mengendalikan indria; kewajiban hidup sederhana; kewajiban mengabdi kepada ācārya; tidak duduk di tempat ācārya; kewajiban mengucapkan salam, penghormatan perkenalan diri; kewajiban menghormati perempuan; kewajiban mengendalikan panca indria; kewajiban berbhakti kepada leluhur dan dewata; berpantang: judi, gosip, bohong, menyakiti, onani/masturbasi, introvert dan seks; kewajiban tidur lebih malam, bangun lebih pagi, makan lebih sedikit dan berpakaian lebih sederhana dari ācārya; menjaga sikap duduk dan sopan santun; pantang menyebut nama guru tanpa gelar kehormatannya; kewajiban menguncarkan mantra suci di waktu subuh dan senja kala; dan kewajiban menghormati ācārya, ayah, ibu dan kakak.
\end{abstract}

Kata Kunci: Ācārya; Brahmacārin; Etika Hindu

\begin{abstract}
This research aims to reveal the brahmacārin ethics in the Manawa Dharmaçastra. This research is a library research with the type of qualitative research. The method in this research is descriptive, using interpretive descriptive analysis. This research used Hans-Georg Gadamer Hermeneutics theory. The primary data source in this research is the Manawa Dharmaçastra. Based on this research, brahmacārin ethics in a review of the Hindu law compendium (Manawa Dharmaçastra) can be concluded as follows: obligation of devotion to God and Ācārya; obligation to dress clean and control the five senses; simple life obligations; obligation to serve $\bar{a} c \bar{a} r y a$; prohibition to sit on the spot of ācārya; obligation to greet others, respect for selfintroductions; obligation to respect women; obligation to control the five senses; obligation to serve ancestors and gods; abstinence to gambling, gossip, lying, hurting, masturbation, introverts, and sex; obligations to sleep late, wake up early, eat less, and dress more modestly than ācārya; maintain a seated attitude and manners; abstain from mentioning teachers names without their honorary titles; obligation to cast holy mantras at dawn and dusk; and obligation to respect $\bar{a} c \bar{a} r y a$, father, mother, and siblings.
\end{abstract}

Keywords: Ācārya; Brahmacārin; Hindu Ethics 


\section{Introduction}

Aristoteles began his metaphysics with a statement "Every human being, by nature, is curious" (Hadi, 1994). The existence of curiosity towards everything is considered to have been built in human creation. Therefore, a curiosity is a fate. It starts from a curiosity to a soul-searching journey. As a result, humans gain something known as knowledge (Tafsir, 2009). This description shows that human relationship with knowledge is always intertwined all the time. Humans seem to have not shown their humanity if they are not supported by a set of knowledge. Therefore, knowledge must be sought because it correlates with human interests. Knowledge is seen as a means to lead humans to become individuals who have competence in managing and overcoming problems, character, happiness, and life goals (UU NO 20 Tahun 2003 Tentang SISDIKNAS, 2003).

The significance of knowledge for humans has synergy with Hindu thoughts which view knowledge as one of the basic needs because knowledge is understood as a human problem solver 'even if you are considered to be the most sinful of all sinners, when you are situated in the boat of transcendental knowledge you will be able to cross over the ocean of miseries (Prabhupada, 2006). In general, knowledge is pursued throughout life, but hierarchically, in the order or stages of life according to Hinduism (Catur Asrama), the search for knowledge is carried out at the earliest stage. This phase is known as brahmacari or the period of gaining knowledge. Brahmacari is a very crucial and fundamental phase of life because it is seen as a starting point as well as a determinant for the next phases, namely grihastha (household phase), wanaprastha (early phase of the spiritual world), and sanyasin or biksuka (spiritual phase) (Budiarta, 2019).

Discussing Brahmacari cannot be separated from the Hindu education system or known as gurukula, a type of spiritual education in ancient India with brahmacārin or śisya, a disciple who lives near or with an $\bar{A} c \bar{a} r y a$ in the same house or place. The $\bar{A} c \bar{a} r y a-$ brahmacārin tradition is sacred in Hinduism. Gurukula comes from the Sanskrit words, Guru means spiritual teacher, and kula means family or home. The brahmacārin learns from $\bar{A} c \bar{a} r y a$ and helps them in daily life, including doing household chores. This activity is one of the methods to shape discipline and character. While living in the gurukula, the brahmacārin are away from their home for months or years and completely cut off from their families. The existence of the brahmacārin is an element in the Hindu education system (gurukula), apart from the $\bar{A} c \bar{a} r y a$. The relationship between the two is sacred and full of ethical values that must be carried out by the students (Joyo, 2020).

Discourse on brahmacāin in the Hindu education constellation or education in general today becomes interesting. Apart from having an interesting and amazing side, such as prestigious achievements in academics, participation in the development of science, and other things, the brahmacārin is also side by side with sad stories such as free sex, abortion, pornography, brawls, and disciplinary action (Maisyaa \& Masitoh, 2019; S. Wulandari, 2019). The deviant behavior that occurs in the brahmacārin is an ironic fact. Instead of becoming a brahmacārin who is intelligent, has good character, has a noble character, and is a someone who is nation's dream, the opposite happens. Therefore, efforts to re-examine ethical values that are inherent in the brahmacārin are relevant and urgent.

In the constellation of Vedas, the source of Hindu law is Manawa Dharmaçastra. This scripture is an authority that elaborates the norms of life according to Hinduism. Among norms or ethics discussed in Manawa Dharmaçastra are; Manawa Dharmaçastra as the source of Hindu law (dharma), samskara, Grihastasrama, wiwaha, yajna, sarddha, how to find the source of life, Snataka, bhoga, Cuntaka, Prayascitta, wanaprasta, samyasa, Duties of the King, civil and criminal law, legal degrees, court proceedings, payment of debts, witnesses, golden scales, debt repayment, savings, sale of property without ownership, awarding of gifts, paying wages, border disputes, insults, slander, theft, adultery, fraud, acts of violence, persecution, murder, husband's duty, wife's duty, distribution of inheritance, gifts, 
grants, alms, tapa-brata, as well as norms that are related to the ethics of brahmacārin (students) in particular. Thus, this scripture bears relevance, significance, and urgency in ethical discourse of brahmacārin compared to other Vedas (Olivelle \& Davis, 2018; Olivelle \& Olivelle, 2005; Pudja \& Sudharta, 2003).

Based on previous research discussing similar topics, there are several of which that are intersect with this research although they do not specifically discuss brahmacārin ethics according to the compendium of Hindu law. Among them are research by 1) I Wayan Mandra and Dhammananda entitled "The Implementation of Tri Hita Karana Teaching to Form Students Characters Quality" (Mandra \& Dhammananda, 2020); 2) I Wayan Artayasa entitled "School Strategies in Embedding Character Education through Dharmagita at SMK Kharisma, Mengwi, Badung" (Artayasa, 2020); 3) A.A. Diah Indrayani and I Kadek Widiantara entitled "Character Education in Satua Anak Agung in Egypt" (Indrayani \& Widiantana, 2020); 4) Ida Bagus Putu Eka Suadnyana and I Putu Ariyasa Darmawan entitled "The Value of Hindu Religious Education in Lontar Siwa Sesana" (Eka Suadnyana \& Ariyasa Darmawan, 2020); 5) I Wayan Agus Gunada entitled "Hindu Teachings in Candrabherawa Geguritan as Strengthening Character Education" (Agus Gunada, 2020); 6) Ida Ayu Gede Wulandari entitled "Lontar Tutur Candrabirawa from the Perspective of Hindu Religious Education" (I. A. G. Wulandari, 2020); 7) Dewa Ketut Wessunawe entitled "Increasing Learning Outcomes of Hindu Religious Education and Character on the Subjects of Tri Murti through Demonstration Methods for Class II Students" (Wessunawe, 2020); 8) I Made Girinata entitled "Building Hinduism Educational Value-based School Culture" (Girinata, 2020); and 9) Ni Luh Adi Palistini entitled "Application of the Peer Tutor Method Can Improve Learning Outcomes of Hindu Religion and Character Education" (Palistini, 2020).

From the literature review, there is no specific similarities in the material objects that were studied in this research. None of the studies dealt specifically with a brahmacārin from the perspective of the Dharmaçastra. In general, it can be stated that this research has a novelty side in the discourse of brahmacārin ethics in the context of Hindu education. From the description above, this study aims to review ethical values for a brahmacārin, especially in the context of Hindu education which is specifically based on the perspective of the Manawa Dharmaçastra.

\section{Methods}

Referring to the material object, this research is a library research. Based on the type of the obtained data, this study is classified as a qualitative research. This research used a descriptive research method by describing the data and facts obtained. The analysis in this research was interpretive descriptive analysis (Ratna, 2009). This research used Hans Georg Gadamer Hermeneutic theory (Hustwit, 2019). The data sources in this research include primary data sources, namely; 1) Manawa Dharmaçastra (Manu Dharma Sastra) or Weda Smrti (Hindu Law Compendium) written by G. Pudja, M.A. and Tjokorda Rai Sudharta, M.A. (2003) published by CV. Nitra Kencana Buana, Jakarta. 2) Hindu Law: A New History of Dharmasastra, edited by Patrick Olivelle and Donal R Davis, JR. (2018) published by Oxford University Press, Oxford. 3) Manu's Code of Law: A Critical Edition and Translation of the Manava-Dharmasastra, written by Patrick Olivelle and Suman Olivelle (2005) published by published by Oxford University Press, Oxford. Meanwhile, the secondary data is a literature source that is relevant to the material object in this study.

\section{Result And Discussion}

\section{Ethics in the Trilogy "The Framework of Hindu Religion"}

The word "ethics" is the Greek language comes from the word ethos and ethikos. Ethos means character, habitual character, while ethikos means morality, civility, behavior, and 
good deeds. The term moral comes from the Latin, mores, which is a plural form of mos which means customs or character habits, character, behavior, and way of life. In Arabic, "ethics" is equivalent to morals, means character, and is in line with the word morality in Indonesian (Bagus, 2000). Ethics is often identified with morals or morality. Even though they are in line with the problems of human behavior, ethics and morals have different meanings. Morality means an understanding of the good and bad values of actions, while ethics means the study of the good and bad. Thus, it can be said that ethics can be used as the theory of good and bad actions. In the field of philosophy, ethics is often equated with moral philosophy.

Ethics is a branch of philosophy that studies human behavior. Considering the pros and cons of human actions in social interactions, Keraf classifies ethics into five (5) parts; 1) descriptive ethics, efforts to assess actions based on the good and bad terms that grow in society; 2) normative ethics, a measure of good and bad based on existing moral norms; 3 ) deontology ethics, assessing good and bad based on whether the action is appropriate or not with its obligations. In other words, an action can be considered as a good deed because it is good in itself so it is obligatory. On the other hand, an action is considered morally bad because it is morally bad, and thus it is not obligatory. Deontology does not question the consequences of actions, whether they are good or bad. The result of the action is not to determine the moral quality of the action; 4) teleological ethics, the good and bad judgment is based on the purpose or the result of the action. An action is considered good if it ends in a good purpose, and vice versa; and 5) virtue ethics, not questioning the consequences of an act, nor based on moral judgments on obligations towards moral law. This ethic prioritizes the development of moral character in each individual (Keraf, 2002).

Hinduism puts ethics into the dialectic of its religious life. Ethics is one of the three important pillars in the trilogy of the Hinduism framework, side by side with tattwa (aspects of knowledge and philosophy) and upacara (rituals). These three things cannot be separated from one another. Tattwa is the basis of the philosophy which becomes appropriate action (ethics) and in the end, these three things lead to a ritualistic space. Hinduism places ethics in a crucial role. Ethics is not only related to the life of society and the world, but also enters spiritual spaces. The Veda states that life exists today is nothing but space where all individuals proceed towards a better level, and the denial of that obligation is a form of denial of the dharma or sacred obligation mandated by God as described in the Sarasamuscaya 3, "Among all living beings, only those who are born as humans can perform good or bad deeds; immerse yourself in good works, all those bad deeds; that is the point of being human"(Karuni \& Suardana, 2018; Nilawati, 2019; Yasa, 2020).

The synergy of the three aspects in tattwa, susila (ethics), and upacara is a must. Their existence is required to be in harmony in time and space. The implementation of ethics will not yield good results if it is not based on the right tattwa. On the other hand, the choice of knowledge, the theory of truth, dharma, religious teachings, philosophy will also not bring benefits if it is not applied in daily practice (ethics) and lived in religious practices (ceremonies). Ethics is an aspect that will complete the religious internalization. This negligent behavior towards ethical aspects makes religious practice less valuable. The actualization of Hindu ethical practices in all walks of life, all professions, and phases of a person's life, including in the person of a brahmacārin. The Ācārya-brahmacārin relationship is full of ethical practices that must be adhered to. Deviating behavior from its norms makes a brahmacārin lose its meaning. If a brahmacārin acts against ethics or politeness towards $\bar{A} c \bar{a} r y a$, they will gain sins instead of knowledge. In Hinduism, an $\bar{A} c \bar{a} r y a$ is a sacred figure (Suhardana, 2006).

\section{2. $\bar{A} c \bar{a} r y \bar{a}$}

Who is a Guru or Acārya? In the Manawa Dharmaçastra II.146, it states 'Utpadakabrahma datra gariyan brahmadah pitah, brahma janma hi wiprasya pretya ceha 
ca cacwatam'. The Sloka explains that $\bar{A} c \bar{a} r y a$ 's position is much more honorable than a father because $\bar{A} c \bar{a} r y a$ gives brahmacārin a knowledge which was meaningful throughout his life in the world and after his death. Upadakabrahma, between the two types of the fathers, for example, makes the body and takes him to the world of knowledge (Veda). Inward rebirth has an eternal reward, wealth in a world is matchless (rich without things), and it is the wealth that is carried to death (Olivelle \& Davis, 2018; Olivelle \& Olivelle, 2005; Pudja \& Sudharta, 2003).

According to Rosen, the word $\bar{A} c \bar{a} r y a$ is often juxtaposed or related with the last name of a Guru who is recognized for the depth of his mastery of Vedic science. Therefore, we came to know the names Sankarācārya, Madhāvācārya, and so on. But the title Ācārya is also given to a prominent Guru who becomes a successor in a sampradaya (spiritual teacher lineage) or spiritual discipline of a particular branch of dharsana or school. The title Ācārya in Hindu culture is given to a Guru who is highly respected for the sanctity of his soul, and whose behavior can be emulated by the wider community. Such titles are given in recognition of the extraordinary merits that have been performed by a spiritual master or Guru in teaching, disseminating, and preserving Vedic teachings (Suryanto, 2011). Ácārya in the Hindu education system has a huge task thus it requires an extraordinary effort of an $\bar{A} c \bar{a} r y a$. The spirit of Hindu education is essentially based on man-making, in this case, students or brahmacārin. Man-making is considered as something artistic and the goal of true education.

In this sense, education is defined as a means of self-realization, a means for the highest goal of life, mukti, or emancipation. The Hindu education system is part of the scheme of life and values. This scheme considers the facts of life and death as a form of necessity and eternal truth. It gives a certain vision of material and spiritual, physical and spiritual, the importance and values of life which are pseudo and permanent and can be clearly interpreted as well as strictly differentiated. According to the ancient Indian Education theory, training the mind and thought processes is fundamental to acquiring knowledge (Suwantana, 2019).

Titib argued that $\bar{A} c \bar{a} r y a$ is a figure who gives education and knowledge to the ignorant, advancing knowledge, and skills. He can distinguish between good and bad (for the brahmacārin), has visionary insight, and wise. Further, he is a community leader, successor of truth, brilliant orator, advances science, educates the morality of the brahmacārin, conditions the brahmacārin to follow the sacred teachings of the Vedas, and protects the sacred traditions (Titib, 1996). According to Altekar, Acārya is "the idea that the guru or teacher is the spiritual father, which is quite common in the Smriti literature that occurs as early as the Atharvaveda. The Baudhayana Dharmasastra declares that a Srotriya or scholar, the ones who teach pupils, cannot be deemed to be issueless" (Altekar, 2009). Ācārya is also defined as "teachers of the Vedic age, were a man of the highest caliber of the society from the point of knowledge and the spiritual progress" (Jayapalan, 2005).

In Taittiriya Upanishad I.11, it is explained that "Matru Devo Bhava, Pirtu Devo Bhava, Acharya Devo Bhava, Atithi Devo Bhava" (Radhakrishnan, 1953). In this sloka, the title $\bar{A} c \bar{a} r y a$ has a very thick spiritual dimension. According to Ācārya Devo Bhava, a Guru is seen as a 'representation' of God, not an ordinary human. Rgveda X.65.7, states that $\bar{A} c \bar{a} r y a$ is a spreader (successor) of truth and orator who are bright and pure as if they had gods' characteristics. Atharvaveda XI.5.8 states "Ācārya tatakșa nabhasī ubhe ime, urvī gambhīre prthivìm divam ca". Acärya acquires knowledge of sky and earth and imparts it to the disciples. Furthermore, Atharvaveda XI.5.16 states "Āchāryo brahmacārī, brahmacārī prajāpatih". Ácärya maintains moral excellence like the creator of the universe (Titib, 1996). From this description, it can be said that $\bar{A} c \bar{a} r y a$ is a central figure in the Hindu education system. Their competence is directly proportional to the duties and responsibilities that are assumed to form the brahmacārin or students. For the brahmacārin, an $\bar{A} c \bar{a} r y a$ is a role model in everything. 


\section{Brahmacārin}

The term brahmacārin comes from a Sanskrit which means student, has faith, is obedient to religion, and live singly. Brahmacärin is also often associated with the word sisyes which means pupil or student (Surada, 2008). Brahmacārin studies from a Guru or Ácārya. In the Upanishad system, the Acārya-brahmacārin relation is described as two important figures in an educational process. Etymologically, Upanishad itself means 'upa' (close), ' $n i$ ' (below), and 'sad' (sitting). Upanishad is a description of the brahmacārin or sisya who sits downstairs near an Acārya. Upanishad means secret teachings, divine teaching, religion, and philosophy. Upanishad is also called 'rahasya jñ̄nna' because of its secret nature of knowledge. Timothy Lubin when commenting on the brahmacārin in his article entitled "The Vedic Student" said, brahmacarya, literally "pursuit or practice of Brahman." This term very early took on a specific technical sense: starting with an initiation by the teacher, symbolically a rebirth, brahmacarya required adherence to a set of disciplinary rules (including celibacy) as well as study, and concluded with a ceremonial bath. The Vedic student (brahmacārin) served his preceptor as an apprentice, residing in his home. It is likely that, at first, it was this training itself that constituted a person as a Brahmin (brähmana), that is, a specialist in Brahman (Olivelle \& Davis, 2018).

During the education process, a brahmacārin has three important obligations, namely 1) Shravana, listening to the truth of the words of a Guru. This knowledge is technically called Sruti (what the ear hears). Pronunciation becomes very vital in this situation. If a word is pronounced differently, the original meaning of the sentence or word will also be different; 2) Manana, the process of interpretation. In this process, a brahmacārin interprets the meaning of Áārya's lesson for himself. At this stage, the brahmacārin undertakes the contemplation of what has been heard; and 3) nididhyasana explains a brahmacārin undertakes activities aimed at a simultaneous, holistic, and complete understanding of Guru's delivery. Nididhyasana is self-realization, contemplation of the essential from what has been intellectually understood to total belief.

Apart from the three things above, the brahmacārin has at least six (6) goals that must be fully pursued to make the learning process effective and successful. The six objectives are self-control, character development, social awareness, integral development of personality, propagation of purity, and preservation of knowledge and culture (Suwantana, 2019).

Gurukula has a unique education pattern and in several aspects has differences with modern education patterns. One of this uniqueness and differences is seen in the Acarryabrahmacārin relation. For the brahmacārin, $\bar{A} c \bar{a} r y a$ is seen as not only a teacher imparting knowledge, but as a person who has a spiritual dimension which seems to be inherent in an $\bar{A} c \bar{a} r y a$. Thus, it is understandable that he is not an ordinary human being with ordinary treatment as well. The distinctive character of the gurukula, when looking at the explanation of the Vedas, one of which lies in the devotion of the brahmacārin to $\bar{A} c \bar{a} r y a$. It looks a little different from the contemporary education pattern where the educational process takes place only in the classroom or at moments of teaching and learning activities. After the teaching and learning process is over, Ācārya and brahmacārin no longer have sufficient communication intensity, and only then will the intensity of communication be rebuilt during the teaching and learning process.

In the gurukula, the educational process goes on almost all the time because in the culture of gurukula education, the brahmacārin will stay with Ācārya or become part of the $\bar{A} c \bar{a} r y a$ 's family. Therefore, this education is called gurukula, namely 'Guru' (Ācārya, an educator) and 'kula' (family or home). In certain space and time, there is a shift in the $\bar{A} c \bar{a} r y a-$ brahmacārin relationship to become a parent-child. In this second position, brahmacārin takes the role of one who is devoted to $\bar{A} c \bar{a} r y a$. The educational process outside the classroom that exists in the gurukula has been seen as having a fundamental influence on the mental development and character of brahmacārin. At that moment, brahmacārin's cognitive and 
theoretical understanding is tested in real life. Classroom descriptions of knowledge and values are actualized in behavior and lead to a lasting inner experience. The values of simplicity, discipline, austerity, independence, persistence, even dilemmas are absorbed in a living experience (Olivelle \& Davis, 2018; Olivelle \& Olivelle, 2005; Scharfe, 2002).

\section{The Brahmacārin Ethics in the Manawa Dharmaçastra (Hindu Law Compendium)}

The material object in this study is brahmacārin ethics which is viewed from the Hindu law compendium and the Manawa Dharmaçastra as the primary source. Based on this study, it can be said that the ethics of a brahmacārin in the context of Hindu education and its specific relationship with $\bar{A} c \bar{a} r y a$ are as follows:

a. Devoting to God to Start Learning

The first ethics taught in Manawa Dharmaçastra II.70 is 'adhyesya manam twacanto yatha çastram prawn mukkah, brahmanjalikrto' dhyapto laghuwasa jitendriyah'. When a brahmacārin is about to study Vedas or sacred knowledge, he begins by chanting the mantra devotional service to God. This form of reverence to God is performed with Brahmaanjali by chanting of the holy mantra Om, repetiting the holy name of God (japa), employing proper sitting (asana), facing east preceded by purification of the breath (pranayama) (Olivelle \& Olivelle, 2005; Pudja \& Sudharta, 2003).

Reverence for God and $\bar{A} c \bar{a} r y a$ is an understandable ethic considering God is the source of knowledge itself as explained in Bhagawadgita IV.1, "śrí-bhagavān uvāca imam vivasvate yogam, proktavān aham avyayam vivasvān manave prāha manur ikșvākave bravīt". Meanwhile, Ácārya described like Taittiriya Upanishad I.11 and Rgveda X.65.7 is a representation of the great soul and the spreader of holy knowledge.

b. Paying Respect to Ācarrya During the Learning

Before brahmacärin starts to study the Vedas, he is obliged to do a reverence for God as well as Áārya. This is stated in Manawa Dharmaçastra II.71; 74; 75; 76; 105; 117; 122. This is explained by one of them in verse II.71 "Brahmarambhe wasane ca diu grahyu gurohsada, samhatya hastawadhye yamsa hi brahmanjalih smrtah". Based on this verse, at the beginning and the end of the lesson, a brahmacārin must pay respect to the Guru by touching the feet of the Guru as a sign of complete sincere devotion. According to the Vedic system, considering that the teachings at that time were oral and the way of writing was not yet known, any teachings that were received had to be heard well and to hear the sacred teachings of the Vedas it was hoped that they would include both hands (Olivelle \& Davis, 2018; Olivelle \& Olivelle, 2005; Pudja \& Sudharta, 2003).

c. Dressing Clean and Controlling the Senses

The second ethic is about dress code and self-control. In the Manawa Dharmaçastra II.70, it described the norm. The dressing is not determined by the price or cheapness, the trend or the fashion, but what should be kept in mind is clean and neat. Thus, there is no reason for a student to ignore the way he dresses, considering this is part of self-discipline.

The next is self-control. There are many disciplines that a brahmacārin must carry out to provide a solid foundation for the character and discipline of a student. Referring to the discipline of sense control, there are general norms that can be used as ethical references for a brahmacārin, which is the teachings of panca yama and nyama brata. They are forms of control of the physical and mental levels. Firstly, panca (yama) is a form of self-control at an outward level, as follows; ahimsa (not hurting), brahmacari (learners and staying away from sexual behavior), satya (true, honest, loyal), awyawahara (not attached to reality), and asteya (not taking the property of others). While panca nyama brata are the five self-control at the mental level, namely; akrodha (self-control), Guru susrusa (respect and devotion to the Guru); sauca (physical and spiritual sanctity); aharalagawa (eating control; simple); and apramada (not denying) (Olivelle \& Davis, 2018; Olivelle \& Olivelle, 2005; Pudja \& Sudharta, 2003). 


\section{d. The Simple Life}

The most important thing for brahmacārin is simplicity. These values are implicitly described in Manawa Dharmaçastra II.108, "Agnimdhanam bhaiksacaryam adhah cayyam gurorhi-tam, acidawartanat kuryat krtopanayo dwijah". 'Simple living high thinking' is a distinctive character of the brahmacārin. In the mantra, sadness is encapsulated metaphorically in the sentence 'sleeping on the floor and living by asking for food.

In the story of Mahabharata, the interpretation of simplicity can be seen when the little Five Pandavas were about to live the life of the brahmacārin. At that time, the five little Pandavas who were the royal family in Hastinapura were economically abundant. Even, the royal party could make a special and luxurious residence for the sons of Pandu, but that did not happen. Instead, when they were about to start their study, the five little Pandavas had their hair cut bald, dressed in the typical clothes of a simple brahmacārin, and not equipped with anything to live in a gurukula with their Guru, Dronacharya. Students of gurukula get equal treatment by the Guru (Olivelle \& Davis, 2018; Olivelle \& Olivelle, 2005; Pudja \& Sudharta, 2003; Titib, 2001).

e. Devotion to Ácārya

Devotion is an inseparable part of the brahmacarin personality. The devotion to $\bar{A} c \bar{a} r y a$ was part of the curriculum of the gurukala. Being with the Guru is meant to allow a brahmacārin to serve them. The intimacy of the Ācarrya-brahmacārin relationship is assumed to be like $\bar{A} c \bar{a} r y a$ and his son, even more so in quality as described in Manawa Dharmaçastra II. 108-109; II.146; II.150.

Verse II.109 Manawa Dharmaçastra explains “"kitrcah cisyo' dhyapya ityaha: Acarya putrah cusrusur njanado dharmikah cucih. Aptah caktorthadah sadhu swodhyapya daca dharmatah'. The word 'dharmatah', means according to law; comply with the rules, or according to holy law. According to Medhaditi, Gowinda, and Narayana, 'dharmatah' means to attain spiritual goodness. The educational intensity in the curriculum is not only about the transfer of knowledge. In this context, devotion to an $\bar{A} c \bar{a} r y a$ has a very attached spiritual dimension, and $\bar{A} c \bar{a} r y a^{\prime} s$ blessing is an important starting point (Olivelle \& Davis, 2018; Olivelle \& Olivelle, 2005; Pudja \& Sudharta, 2003).

f. Prohibition to Sit at $\bar{A} c \bar{a} r y a$ 's Place

Upanisad means sitting down near $\bar{A} c \bar{a} r y a$. This Upanisad method explains the ethics of sitting between the student and the Guru. Students must sit under the Guru so ethically, not side by side with the Guru. A low-high position indicates who is in a position of respect. Thus, sitting attitude becomes standard ethics in the Hindu education system. Therefore, a student is not allowed to sit in the seat of a teacher, as explained in Manawa Dharmaçastra II.119, "Çayyasane' dhyacarite creyasa na samawiçet çayyasanasthaçcaiwainam pratyut chayabhiwadayet".

This verse is the basis for a code of ethics that prohibits someone from occupying places and specifically designated for honorable people. For example, someone who is not a judge occupies the seat of a judge, an ordinary employee because there is no coincidence the leader is there, then he is the one who occupies the chair of the leader, or the brahmacārin which coincidentally the $\bar{A} c \bar{a} r y a$ is not in the gurukula, positions himself in that chair (Olivelle \& Davis, 2018; Olivelle \& Olivelle, 2005; Pudja \& Sudharta, 2003).

g. Saying Greetings and Respect to Older People and Introducing Yourself

In the Manawa Dharmaçastra II.120, "asyarthawadamaha; urdhwam prana hyut kramauti, yunah sthawira ayati, prayuthana bhiwadabhyam panastan prati padyata". 'Asyartha wada maha' means that a younger person or someone who is also in a lower position is encouraged to get up (if he is in a sitting position) and pay respect when a parent or a respected person (sthawira) comes near him.

The explanation regarding the ethics of this respect is continued in the verse Manawa Dharmaçastra II.122, "Sampratyabhiwadanawidhmaha; abhiwadatparam wiprojyayam 
samabhiwadayet, asau namahamasmiti swam parikirtayet name". After respecting (abhiwada) for example by saying 'Om Swastyastu, Namaste, Namaskaram, or Abhiwadaye' which means I prostrate to Thou so that he introduces himself by saying his name and origin. This provision is the basis of social ethics to state the name and origin. The ethics of respect is also explained in II.124, "Bhoh çabdam kirtyedante swasya namno' bhiwadane namnam swa rupabhawo hi bhobhawa rsibhih smrtah," It is the salutation and pronunciation of the word 'bhoh,' after pronouncing his name (Olivelle \& Davis, 2018; Olivelle \& Olivelle, 2005; Pudja \& Sudharta, 2003).

h. Respecting Women

Entering a period of demanding knowledge (brahmacarya), a brahmacārin introduced an ethic towards women. On Manawa Dharmaçastra II.131, "Matrswasa matulani çwaçruratha pitrswasa, sampujva gurupatni watsa masta guru bharyaya". According to this verse, an aunt, the wife of an uncle, a daughter-in-law, must be respected as befits a Guru's wife. So that her position is equalized to that of a Guru's wife (Olivelle \& Davis, 2018; Olivelle \& Olivelle, 2005; Pudja \& Sudharta, 2003).

In Hinduism, a woman has a respectable position. Her capacity and role are significant, making a woman so respected. There is no impression of degrading or even placing women lower than men. The position of men and women in Hinduism is essentially egalitarian. Yajurveda XIV.21, stated "Mūrdhā-asi rād dhruvā-asi dharunā dhartrī-asi dharanī. Ā yușe tvā varcase tvā krsyai tvākșemāya tvā". This verse explains the important role and position of women, especially in the family. It is stated that a woman is a pioneering figure, a symbol of brilliance, stability, support, she who provides food and observes rules like the earth. The existence of women in a family is seen as a figure who gives longevity, brilliance, prosperity, fertility, and prosperity (Titib, 1996).

Rigveda VIII.33.19 describes 'Strī hi brahma babhūvitha', a woman in this verse is a scholar and a teacher. Thus, the female figure is a scholar. According to Hinduism, women are the first and foremost people in providing education and teaching to their children in a family. Women become one of the role models in the family. The way a mother thinks, speaks, and acts are examples for her children.

Furthermore, the figure of Dewi Kunti in her daily life is a mindful person considering that she is a mother of five sons. The outcome of family education by Dewi Kunti is visualized in the figures of Yudhistira, Bima, Arjuna, Nakula, and Sahadewa who have noble characters. This is different from Dewi Gandari, the wife of King Hastinapura who gave bad influence to her sons (Kaurawa). Regarding this, it is also supported by several scientific studies on the influence and role of a mother or parent in the context of children's education (Latifah, 2020). i. Controlling the Five Senses

Manawa Dharmaçastra II. 175-178 implicitly explores this. "Sewete mamstu niyaman brahmacarigurau was am, sanniyamyendriya graman tapo wrddhyartham atmanah" means a brahmacārin who lives with a Guru must be obliged to follow the rules and stay away from the prohibitions as explained by Manawa Dharmaçastra II.175. According to Pudja and Sudharta, rules according to this verse are the necessity to control the five senses and this can increase someone's spirituality (Pudja \& Sudharta, 2003). Controlling of the five senses can be said as a form of control over things related to the sense of touch, sense (skin), sense of sight (eyes), sense of hearing (ears), sense of smell (nose), and sense of taste (tongue).

One of the actualizations of this form of control, for example, is control of the sense of taste (tongue). A brahmacārin is not allowed to indulge the taste of the tongue. Life is not to satisfy the tongue, meaning that eating is not to follow the taste of the tongue. In principle, eat to live, not live to eat. The ethical form of this discipline in the five nyama brata is known as aharalagawa (the prohibition to not eat much). These forms of restraint are also confirmed in Manawa Dharmaçastra II.57. 'Atibhojane dosamaha' explains that eating too much is harmful to health (causes suffering) (Olivelle \& Davis, 2018). 
The same thing is also found in Manawa Dharmaçastra II.192, "Çaritram caiwa wacam ia buddhindriyam anamsi ca, niyamya pranjalististhe dwiksamano guror mukha". By controlling the body and maintaining the body's steps people can control the words, the five senses, and the mind. It can lead people to always speak kindly, politely, and using subtle words. Furthermore, it prevents indulging in sensuality, always being alert, and thinking clearly.

Canakya Nitisastra also explains this in verse 10, 'kamam krodhah tatha lobham svadam srnggara kautukam ati nidrati seva ca Vidyarthi hyasta varjayet'. The form of selfcontrol conveyed in the verse is that a brahmacārin must hold the lust, anger, greed, enjoyment of the tongue, preening, playing around, and sleeping too much (Suhardana, 2006). j. Making Offerings to the Ancestors and Devata (God)

The next ethic is about the offering that must be done by a brahmacārin, the offerings addressed to the Gods and Ancestors. This is described in Manawa Dharmaçastra II.186, "nityam snatwa çucih kuryad dewarsi pitr terpanam dewatabharcanam caiwa samidadhanamewa ca". 'Air suci' means pure water, 'tarpana' is an offering or treat in the form of food and drink served to the ancestors, while 'Dewatabhyarcanam' is an offering to the Devata that can be made by burning sandalwood on holy fire, for example at pasopan (Olivelle \& Davis, 2018; Olivelle \& Olivelle, 2005; Pudja \& Sudharta, 2003).

Honoring ancestors with altars, temples, rong tiga, padmasari, prayers, and certain rituals is not a new practice in Hinduism. Even over thousands of years, those practices by indigenous peoples around the world have placed special spaces and places to express sacred connections to its roots. Why are ancestors so respected in Hinduism? an important question that is often heard. Respect for ancestors is a consequence and implication of the basic Hindu philosophy of respect for them. One source that states this is the Taittiriya Upanishad I.11, described "Matru Devo Bhava, Pitru Devo Bhava, Acharya Devo Bhava, Atithi Devo Bhava". 'Pitru Devo Bhava' means that ancestors are also a manifestation of the spirit of the Gods, Brahman or God. This meaning is only in philosophical and symbolic language.

Likewise, an offering to Devata is a sign of devotion. The theological attitude recognizes that all of this existence originates from 'Brahman'. This is described in the Isa

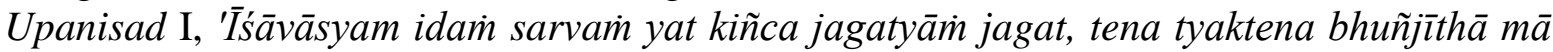
grdhah Kasya Svid Dhanam'. This verse means that all existence in this world, including whether it has a soul or not, is all controlled by $\bar{I} s^{\prime} \bar{a}$ or God. It is suggested that man should be content with what has become his own and not that of others because basically possession is transitory, false. The true possessor is none other than Íśa or God (Adnyana, 2019; Andrijanić, 2009; Cohen, 2009; Pudja \& Sudharta, 2003; Skorokhodov, 2016; Smith et al., 2002). Starting from this philosophical basis, both the gods and their ancestors (pitru) are so respected in Hinduism and become an integral part of the daily ritualistic activities of a brahmacārin.

k. Abstinence: Gambling, Gossip, Lying, Hurting, Masturbation, Introverts, and Sex

The following are behaviors no one should do as a brahmacārin, Manawa Dharmaçastra II.179-180, "Dyutam ca janawadam ca pariwadam tathanrtam, strinam ca preksanalambham upaghatam parasya ca". The phase of studying is a period in which Hindus character is forged from an early age. Various disciplines and ethics are applied very strictly during the study because this has a devastating effect and has the potential to destroy the future of the brahmacārin (Olivelle \& Davis, 2018; Olivelle \& Olivelle, 2005; Pudja \& Sudharta, 2003).

Referring to the verse, the prohibited behaviors that must be avoided are gambling, gossiping, lying, hurting, masturbation, introverts, and engaging in sexual or free sex. One of the examples is the practice of free sex among the brahmacārin. This behavior contributes to cases of abortion and teen suicide. Various scientific studies have shown this data. Therefore, the ethical principles applied in the Hindu Education system are more like self-awareness and preventive action (Nancy Naomi Aritonang, 2019). 
1. Sleep Late, Wake Up Earlier, Eat Less, and Dress Simpler

Manawa Dharmaçastra II.194 discusses the details that a brahmacārin must do, 'Hinannawastra wesah syat sarwada gurusnidhau, uttisthat prathamam casya caranam caiwa sam wicet', meaning that the brahmacārin should sleep after making sure the $\bar{A} c \bar{a} r y a$ has slept first. Likewise, a brahmacārin should wake up earlier. It is also applied in eating. A brahmacārin is not advised not to go ahead of the Guru and the way of dressing is no different in ethics (Olivelle \& Davis, 2018; Olivelle \& Olivelle, 2005; Pudja \& Sudharta, 2003).

At first glance, this ethic seems less logical. However, this can be understood as one of cultivating the values of humility, simplicity, discipline, respect as told by the little Pandavas when he was under the care of Dronacharya. As a royal son, it is certainly not a difficult matter to provide material luxury, but it is not done. The result of this discipline eventually made students who were tough, intelligent, and noble characters.

m. Maintain a Sitting Attitude and Courtesy

Manawa Dharmaçastra II.195-198, explains the ethics of sitting for a brahmacārin. For example, in II.198, "Nicam çayyasanam casya sarwada gurusnidhau, girostu caksru wisaye na yathestasane bhawet". The verse explains that a student's bed and seat should have a lower position than the Guru. Likewise, the sitting posture must always be maintained. You are not allowed to sit carelessly, especially if you are in the eyes of the Guru (Olivelle \& Davis, 2018; Olivelle \& Olivelle, 2005; Pudja \& Sudharta, 2003).

n. Do Not Call Teacher's Name without Honors

Brahmacārin ethics is also about the way of addressing Guru. It is almost not found in Hindu culture that a teacher is called without an honorary title. Especially in the environment of the gurukula in the Ācarrya-brahmacārin relationship because this would be very contrary to ethical values in the gurukula tradition. Manawa Dharmaçastra II.199 explains "nodaharedasya the name of the paroksam api kewalam, na caiwa ana kurwita gati bhasi castitam".

It is stated that a brahmacārin is not allowed to just mention the name of his Guru without being given an additional title of respect. There are several names in honor of those known in the Hindu tradition, including the title upadhaya; Bhatta (medhaditi); Ācārya (Kulluka) or Carana (Narayana) and in Indonesia there are various titles: Ida; Mpu; Pedanda Gede, Dewa Agung, and so forth (Olivelle \& Davis, 2018; Olivelle \& Olivelle, 2005; Pudja \& Sudharta, 2003).

o. Cast the Holy Mantra at Dawn and Dusk

One of the important and mandatory tasks that must be performed by a brahmacārin according to the instructions of the scriptures is casting the sacred mantra at dawn and dusk as stated in Manawa Dharmaçastra II.222, "Yasmadukta prakarena samdhyati; krame mahat papa matah. Acamya pravato nityam uthesamdhye samahitah, cucao dece japanjapyam upasita yathawidhi". After purifying oneself, brahmacārin unites the mind in a holy place and cast a holy mantra (japa) according to the rules (Olivelle \& Davis, 2018; Olivelle \& Olivelle, 2005; Pudja \& Sudharta, 2003).

Chanting is a practice in Hinduism. Bhagavata Purana VII.5.23 explains Nawa Laksana Bhakti or nine ways of devotional service, "Sravanam kirtanam visnoh smaranam on sevanam Arcanam vandanam dasyam sakhyam atma nivedanam". The nine parts are; 1) Sravanam, learning the greatness of God through reading or listening to the Vedas; 2) Kirtanam, say/sing the holy name of God; 3) Smaranam, remembering God's holy name or meditating on Him; 4) Padasevanam, service to God, including helping all beings; 5) Arcanam, worshiping God through 'niyasa' God and offerings of food, flowers, water, incense and so on; 6) Vandanam, devotion to God; 7) Dasya, serve or help all beings; 8) Sakhya, seeing God as a true friend; and 9) Atmanivedanam, self-surrender to God (Joyo, 2018).

The chanting of holy mantras, kirtanam, smaranam, is a very important sadhana (spiritual practice) in the Vedas. These activities not only carry the sign of devotional service 
to God but also have tremendous positive psychological and spiritual effects and benefits. This practice has brought so many Hindus to a very significant increase in spiritual awareness, and in the end, it has a positive effect on other aspects of life, such as mental health (psychic) and physical health benefits. Various scientific studies show the positive benefits of these activities (Ghaligi et al., 2006; Kori, 2017; Manabe, 2019; Rao et al., 2018; Singh \& Singh, 2018).

p. Respect $\bar{A} c \bar{a} r y a$, Father, Mother, and Brother

Furthermore, four (4) important figures must be respected by a brahmacārin, namely Guru, father, mother, and brother as stated in Manawa Dharmaçastra II.225 - II. 237. 'Ācāryo brahmano murtih pita murtih prajapatih, mata prthiwya murtistu bharata swo murti atmanah", this mantra is an excerpt from verse II.226. The verse explains that actually, Guru $(\bar{A} c \bar{a} r y a)$ is a picture of Brahman, the father is an image of Prajapati, the mother is a picture of Prthiwi and brother is a picture of oneself. The commentary on the importance of these figures has been widely stated in the Vedas, among others; Taittiriya Upanishad, Mabharata, Ramayana, Regveda, Canakya Nitisastra, and so forth (Olivelle \& Davis, 2018; Olivelle \& Olivelle, 2005; Pudja \& Sudharta, 2003; Suhardana, 2006; Titib, 1996).

This is the result of a review of the brahmacārin ethics in the Manawa Dharmaçastra, which is specifically described in the book (adhyaya II). Based on the studies conducted, basically, the values that have been stated have relevance to the present. Why is that? It is better understood that these values are universal, thus the spirit can be contextualized throughout the ages.

\section{Conclusion}

Based on the studies that have been done, then can conclude brahmacārin ethics in the review of the Hindu legal compendium (the Manawa Dharmaçastra) as follows: devotional obligations to God and $\bar{A} c \bar{a} r y a$; obligation to dress clean and restrained by the senses; obligation to live simply; obligation to serve $\bar{A} c \bar{a} r y a$; prohibition to sit on the $\bar{A} c \bar{a} r y a$ 's place; obligation to say greetings, respect for self-introductions; obligation to respect women; obligation to control the five senses; obligation to serve ancestors and Devata; abstinence of gambling, gossip, lying, hurting, masturbation, introverts, and sex; obligations to sleep later, wake up earlier, eat less and dress more modestly than $\bar{A} c \bar{a} r y a$; maintain a seated attitude and manners; abstinence from mentioning teachers' names without their honorary titles; obligation to cast holy mantras at dawn and dusk; and obligation to respect $\bar{A} c \bar{a} r y a$, father, mother, and brother.

\section{References}

Adnyana, P. E. S. (2019). Brahma Vidyā Dalam Kitab İsāa Upaniṣad (Studi Teologi Hindu). Jurnal Pangkaja: Jurnal Agama Hindhu, Volume 22.

Agus Gunada, I. W. (2020). Ajaran Agama Hindu Dalam Geguritan Candrabherawa Sebagai Penguatan Pendidikan Karakter. Kamaya: Jurnal Ilmu Agama, 3(2). https://doi.org/10.37329/kamaya.v3i2.434

Altekar, A. S. (2009). Education in Ancient India. Isha Books. .

Andrijanić, I. (2009). Vedāntic Commentaries on the Îsā-upanisad. Obnovljeni Život : Časopis Za Filozofiju i Religijske Znanosti, 64.(1).

Artayasa, I. W. (2020). Strategi Sekolah dalam Menanamkan Pendidikan Karakter Melalui Dharmagita di SMK Kharisma, Mengwi, Badung. Kalangwan Jurnal Pendidikan Agama, Bahasa Dan Sastra, 10(1). https://doi.org/10.25078/klgw.v10i1.1398

Bagus, L. (2000). Kamus Filsafat. PT. Gramedia Pustaka Utama.

Budiarta, I. W. (2019). Penerapan Pendekatan Belajar Catur Asrama Melalui Taksonomi Tri Kaya Parisudha dalam PKN (Studi Quasi Experiment Terhadap Peningkatan Kompetensi Kewarganegaraan Siswa SMA Negeri Di Kota Singaraja). Jurnal Media 
Komunikasi Pendidikan Pancasila Dan Kewarganegaraan, 1(1), 36-53. https://doi.org/10.23887/jmpppkn.v1i1.10

Cohen, S. (2009). Chapter Eight. The İsaa Upanișad. In Text and Authority in the Older Upaniṣads. https://doi.org/10.1163/ej.9789004167773.i-320.101

Eka Suadnyana, I. B. P., \& Ariyasa Darmawan, I. P. (2020). Nilai Pendidikan Agama Hindu Dalam Lontar Siwa Sasana. Cetta: Jurnal Ilmu Pendidikan, 3(2). https://doi.org/10.37329/cetta.v3i2.460

Ghaligi, S., Nagendra, H., \& Bhatt, R. (2006). Effect of Vedic chanting on memory and sustained attention. Indian Journal of Traditional Knowledge (IJTK), 05(2).

Girinata, I. M. (2020). Building Hinduism Educational Values-Based School Culture. Jurnal Penelitian Agama Hindu, 4(1). https://doi.org/10.25078/jpah.v4i1.1382

Hadi, P. H. (1994). Epsitemologi Filsafat Pengetahuan (Kenneth T. Gallagher). Kanisius.

Hustwit, J. R. (2019). Hans-Georg Gadamer (1900-2002). In Religion and European Philosophy. https://doi.org/10.4324/9781315642253-25

Indrayani, A. A. D., \& Widiantana, I. K. (2020). Pendidikan Karakter Dalam Satua Anak Agung Di Mesir. Cetta: Jurnal Ilmu Pendidikan, 3(2). https://doi.org/10.37329/cetta.v3i2.453

Jayapalan, N. (2005). History of Education in India. Nice Printing Press.

Joyo, P. R. (2018). Bhakti Marga: Jalan Menuju Tuhan Melalui Cinta Kasih. Dharma Duta, 16(1). https://doi.org/10.33363/dd.v16i1.151

Joyo, P. R. (2020). Nilai Nilai Pendidikan Hindu dalam Slokantara (I. N. Duija (ed.)). CV. Jakad Media Publishing.

Karuni, N. K., \& Suardana, I. W. (2018). Wacana “Ajeg Bali” Pada Seni Kerajinan Sarana Upacara Di Gianyar Bali. Mudra Jurnal Seni Budaya, 33(1). https://doi.org/10.31091/mudra.v33i1.321

Keraf, A. S. (2002). Etika Lingkungan. Kompas.

Kori, J. (2017). Effect Of Chanting Omkara Mantra On Pulse Rate For Stress Reduction. International Journal of Advance Engineering and Research Development, 4(07). https://doi.org/10.21090/ijaerd.19352

Latifah, A. (2020). Peran Lingkungan Dan Pola Asuh Orang Tua Terhadap Pembentukan Karakter Anak Usia Dini. (JAPRA) Jurnal Pendidikan Raudhatul Athfal (JAPRA), 3(2). https://doi.org/10.15575/japra.v3i2.8785

Maisyaa, I. B., \& Masitoh, S. (2019). Derajat Keterpaparan Konten Pornografi Pada Siswa Smp Dan Sma Di Dki Jakarta Dan Banten Indonesia. Jurnal Kesehatan Reproduksi, 10(2).

Manabe, N. (2019). Women's March Colloquy - Chants of the Resistance: Flow, Memory, and Inclusivity. Music and Politics, 13(1). https://doi.org/10.3998/mp.9460447.0013.105

Mandra, I. W., \& Dhammananda, D. (2020). Implementation Of Tri Hita Karana Teaching To Form Students Characters Quality. Jurnal Penjaminan Mutu, 6(1). https://doi.org/10.25078/jpm.v6i1.1300

Nancy Naomi Aritonang, M. P. (2019). Gambaran Perilaku Percobaan Bunuh Diri Pada Remaja Putri Yang Broken Home Nancy. JURNAL STINDO PROFESIONAL, 5.

Nilawati, I. G. A. (2019). Pendidikan Etika Hindu Pada Teks Agastya Parwa Dalam Kehidupan Modern. WIDYANATYA, 1(1). https://doi.org/10.32795/widyanatya.v1i1.269

Olivelle, P., \& Davis, D. R. (2018). Hindu Law: A New History of Dharmasastra. Oxford University Press.

Olivelle, P., \& Olivelle, S. (2005). Manu's Code of Law: A Critical Edition and Translation of the Manava-Dharmasastra. Oxford University Press.

Palistini, N. L. A. (2020). Penerapan Metode Tutor Sebaya dapat Meningkatkan Hasil Belajar Pendidikan Agama Hindu dan Budi Pekerti. Jurnal Ilmiah Pendidikan Profesi Guru, 3(2). https://doi.org/10.23887/jippg.v3i2.29086

Prabhupada, A. C. B. S. (2006). Bhagavad-gita Menurut Aslinya. Hanuman Sakti. 
Pudja, G., \& Sudharta, T. R. (2003). Manawa Dharmacastra (Manu Dharmacastra). CV. Nitra Kencana Buana.

Radhakrishnan, S. (1953). The Principal Upanisads. George Allen and Unwin LTD .

Rao, N. P., Deshpande, G., Gangadhar, K. B., Arasappa, R., Varambally, S., Venkatasubramanian, G., \& Ganagadhar, B. N. (2018). Directional brain networks underlying OM chanting. Asian Journal of Psychiatry, 37. https://doi.org/10.1016/j.ajp.2018.08.001

Ratna, N. K. (2009). Teori, Metode dan Teknik Penelitian Sastra. Pustaka Pelajar.

Scharfe, H. (2002). Education in Ancient India. Brill.

Singh, R., \& Singh, S. K. (2018). Gayatri Mantra Chanting Helps Generate Higher Antimicrobial Activity of Yagya's Smoke. Interdisciplinary Journal of Yagya Research, 1(1). https://doi.org/10.36018/ijyr.v1i1.6

Skorokhodov, T. G. (2016). Ethical monotheism versus Hindu polytheism: The interpretation of Isha Upanisad in the religious thought of Rammohan Raya. In Voprosy Filosofii (Issue 4).

Smith, F. M., Olivelle, P., \& Roebuck, V. J. (2002). The Early Upanisads: Annotated Text and TranslationThe Upanisads. Journal of the American Oriental Society, 122(1). https://doi.org/10.2307/3087700

Suhardana, K. M. (2006). Pengantar Etika dan Moralitas Hindu. Paramita.

Surada, I. M. (2008). Kamus Sanskerta Indonesia. Paramita.

Suryanto. (2011). Transformasi Figur, Karakter, dan Peranan ācārya dalam Sastra Hindu India ke Dalam Dunia Wayang Kulit Purwa di Jawa.

Suwantana, I. G. (2019). Pembentukan Karakter Anak Dalam Sistem Pendidikan Hindu Kuno. Adi Widya: Jurnal Pendidikan Dasar, 2(2), 8. https://doi.org/10.25078/aw.v2i2.959

Tafsir, A. (2009). Filsafat Ilmu (Mengurai Ontologi, Epistemologi dan Aksiologi Pengetahuan). PT. Remaja Rosdakarya.

Titib, I. M. (1996). Veda Sabda Suci Pedoman Praktis Kehidupan. Paramita.

Titib, I. M. (2001). Filosofi Pendidikan Hindu Menurut Weda, Konsep dan Kemungkinan Implementasinya di Indonesia.

UU NO 20 Tahun 2003 Tentang SISDIKNAS, 1 (2003).

Wessunawe, D. K. (2020). Peningkatan Hasil Belajar Pendidikan Agama Hindu dan Budi Pekerti Pada Pokok Bahasan Tri Murti Melalui Metode Demonstrasi Pada Siswa Kelas II SD. Jurnal Riset Intervensi Pendidikan (JRIP), 2(2). https://doi.org/10.36765/jrip.v2i2.239

Wulandari, I. A. G. (2020). Lontar Tutur Candrabherawa Perspektif Pendidikan Agama Hindu. JURNAL YOGA DAN KESEHATAN, 2(1). https://doi.org/10.25078/jyk.v2i1.1552

Wulandari, S. (2019). Perilaku Seksual Pranikah Berisiko Terhadap Kehamilan Tidak Diinginkan PadaRemaja SMKN Tandun Kabupaten Rokan Hulu. Journal of Chemical Information and Modeling, 53(9).

Yasa, P. D. (2020). Ajaran Kelepasan Dalam Lontar Tutur Kumara Tattwa. JURNAL YOGA DAN KESEHATAN, 2(2). https://doi.org/10.25078/jyk.v2i2.1565 